UDC 37.012.85

DOI https://doi.org/10.24919/2308-4863/45-2-27

Ievheniya POSTYKINA, orcid.org/0000-0003-2675-0224

Senior Lecturer at the English Language Department Petro Mohyla Black Sea National University (Mykolaiv,Ukraine) postykina@yahoo.com

\title{
USE OF IT (INFORMATION TECHNOLOGIES) IN THE WORK WITH STUDENTS OF THE ECONOMIC SPECIALITIES
}

The widespread development of information technologies and their penetration into the spheres of society determine the world development over the past few decades. This process requires the training of a sufficient number of qualified specialists, as well as an increase in the overall level of computer literacy. This requires the improvement and structural change of the education system, as well as the provision of modern material and technical equipment of the educational process.

New information technologies are a set of mathematical and cybernetic methods, modern technical means that ensure the collection, storage, processing and transmission of information on the basis of modern computer technology. The main objectives of new information technologies of learning are the development of interactive environments for managing the process of cognitive activity and access to modern information and educational resources.

It should be emphasized that in pedagogy, interest in information technology is associated, first of all, with the solution of the problem of creating a high-quality educational base, in particular electronic learning tools. It is the effective use of new information technologies, their competent infusion into the pedagogical process of teaching various disciplines, the creation of a single information environment in the educational institution and in education as a whole that will allow the transition to a new modern concept of education.

Modern education provides for a significant expansion of the role of information technology as an effective means of self-development, self-improvement and self-education of students.

Currently, there is a problem of forming a set of professional competencies among teachers that are necessary for effective work in modern conditions. Teaching and teaching in conditions of excess information, orientation to the formation of the ability to independently learn and "obtain" knowledge require a significant replenishment and change of the traditional methodological baggage.

Key words: unformatted technologies, qualified specialists, pedagogical science, self-education, economic specialities.

Свгенія ПОСТИКІНА, orcid.org/0000-0003-2675-0224 в.о. старшого викладача кафедри англійської мови Чорноморського національного університету імені Петра Могили (Миколаїв, Україна) postykina@yahoo.com

\section{ОСОБЛИВОСТІ ВИКОРИСТАННЯ ІТ (ІНФОРМАЦІЙНИХ ТЕХНОЛОГІЙ) У РОБОТІ ЗІ СТУДЕНТАМИ ЕКОНОМІЧНОГО НАПРЯМКУ}

\footnotetext{
Широкий розвиток інформаційних технологій та їхнє проникнення у сфери жсття суспільства визначають світовий розвиток за останні кілька десятиліть. Цей прочес вимагає підготовки достатньої кількості кваліфікованих фахівиів, а також підвищення загального рівня комп 'ютерної грамотності. Це вимагає вдосконалення та структурної зміни системи освіти, а також забезпечення сучасним матеріально-технічним оснашенням навчального процесу.

Нові інформачійні технології - ие сукупність математичних і кібернетичних методів, сучасних технічних засобів, що забезпечують збір, зберігання, обробку й передачу інформації на основі сучасних комп'ютерних технологій. Основними завданнями нових інформаційних технологій навчання є розвиток інтерактивних середовищ для управління прочесом пізнавальної діяльності та доступу до сучасних інформачійно-освітніх ресурсів.

Слід підкреслити, щьо в педагогіиі інтерес до інформаиійних технологій пов 'язаний, пери за все, з виріменням проблеми створення якісної освітньої бази, зокрема електронних інструментів навчання. Саме ефективне використання нових інформачійних технологій, їх грамотне вливання в педагогічний процес викладання різних дисичиплін, створення єдиного інформаційного середовища в навчальному закладі та в освіті загалом дадуть змогу перейти до нової сучасної концепиії освіти.

Сучасна освіта передбачає значне розширення ролі інформаиійних технологій як ефективного засобу саморозвитку, самовдосконалення та самоосвіти студентів.

Наразі існує проблема формування набору професійних компетениій серед викладачів, необхідних для ефективної роботи в сучасних умовах. Викладання і викладання в умовах надлишкової інформащії, орієнтація на формування здатності самостійно вчитися та здобувати знання вимагають значного поповнення $і$ зміни традииійного методичного багаюу.

Ключові слова: інформаційні технологї, кваліфіковані спеціалісти, педагогіка, самоосвіта, економічні спеціальності.
} 
The use of IT in modern education is dedicated by the rapid development of the information society, the wide spread of multimedia technologies, electronic information resources, allow the use of information technologies as a means of learning, communication, education, integration into the world space. A modern teacher should be able to use universities with information technologies and be able to use them in the educational process. In order to form the necessary integrative qualities of a student with economic direction ensures a full transition to the next level of the education system, the university teacher must harmoniously combine traditional teaching methods with modern information technologies.

In the IT era, when the computer is a necessary attribute of the means of teaching students in the economic direction, the question of the use of information-economic technologies in the educational process is very relevant. IT is often used as a means of exchanging information and as a means of creating something new.

The theory and practice of using computer technologies in training were carried out by such scientists as: M. Y. Bukharkin, D. S. Sailor, A. A. Kuznetsov, V. M. Monakhov, O. K. Tikhomyrov, A. P. Yershov, S. A. Khrystochevsky and others. The influence of new IT on improving the effectiveness of the learning process is indicated in the researches of Y.K. Babansky, E.A. Barakhsanovo, T.V. Gabai, A.M. Korotkov.

Computer technologies can be considered as a means of mental development of a person. Methodological aspects of education development in the era of new IT are considered in the works of T.A. Vladimirova, T.P. Voronina, T.S. Georgieva, O.P. Molchanova, T.V. Sergeeva and others. Informatization of education is considered by us as the main way to overcome the crisis of education through the development of new models of education, the introduction of new technologies and theories of learning.

The purpose of the study is to theoretically substantiate and experimentally test the effectiveness of IT use in the work of the teacher with students in the economic direction of study.

The object of research is the process of using IT in the work of the teacher with students of the economic direction of study.

The subject of the study is the pedagogical conditions for the effective use of IT in the work of the teacher with students of the economic direction of study.

In the course of informatization, education is rapidly moving forward, and university teachers have no choice but to meet the conditions for the development of the information age. The use of computers in all spheres of human activity, the development of network technologies, generates modern problems and gives impetus to the development of new areas of research. The search for effective methods of its application in education, the study of psychological and pedagogical aspects of human-computer interaction are of particular importance nowadays. To date, students of universities and their interests are in the spotlight. Students need to rapidly be included in the learning process and stop being the object of influence. Great opportunities in order to implement this task are laid down in the use of IT in universities (Voronina, 2005: 6). The introduction of IT in the work of a university teacher contributes to improving the quality of education, increasing the availability of education, ensuring the harmonious development of the child's personality, which is oriented in the information space.

The use of IT in the course of the educational process of universities allows it to modernize and increase the effectiveness of education, increase the motivation for teaching students in the economic direction of education, as well as develop their intellectual abilities of students in the economic direction of education.

The problem of widespread use of modern IT in education and education over the past decade has caused the interest of many authors in the national pedagogical science. Great contribution to solving the problem of modern information technology of training made Russian and foreign scientists: G. R. Gromov, V. Hrytsenko, V. F. Sholokhovic, O. I. Agupova, O. A. Kryvosheev, S. Peypert, G. Klayman, B. Sandy, B. Hunter and others. Various didactic problems of computerization of training in our country were reflected in the works of A. P. Yershov, A. A. Kuznetsov, T. A. Sergeeva, I. V. Robert; methodical - B. S. Gershunsky, E. I. Mashbitz, N. F. Thalizina; psychological - V. V. Rubtsova, V. V. Tikhomyrova and others.

In accordance with the professional standard of interaction of the teacher with students should work teachers who are well-knowledgeable in technology and know the technical capabilities of the computer, are oriented in computer programs developed directly for students of the economic direction of preschool education, have a methodology to attract students of the economic direction of education to new technologies. Acquaintance of students in the economic direction of LEARNING with IT can occur in different ways, however, first of all, the teacher himself must have the basic set of knowledge, skills and abilities so that this acquaintance can take place. Theoretical bases of information and communication 
technologies in education are laid in the works of A. Y. Uvarov, V. A. Krasilnikova, G. M. Kiselyova, V. E. Peshkova, R. V. Bochkovy and others.

The formation of information and communication technologies were engaged in such scientists' works as: O. V. Akulova, O. B. Zaitseva, A. G. Peksheva, S. V. Trishyna and others. Informatization of education were engaged E. V. Danylchuk, L. F. Ivanova and others. The problems of determining the essence of the information competence of the teacher and its content are studied in the works of Y. I. Askerko, E. V. Burkova, S. A. Bykova, D. V. Holubina, M. V. Goryacheva, A. B. Hoferberg, N. V. Kisil, I. A. Kuluntaevoy. Among scientific studies, the special significance is the works in which the content of the concept of "IT competence" is considered (L. A. Basurmatova, L. S. Husnutdinova). The search and analysis of the optimal ways and methods of introducing information and communication technologies in pedagogy and the field of education is carried out not only by scientists: psychologists, teachers, methodologists, specialists in the field of computer science and computer science, but also employees of the education system who focus on practice (B. S. Gershunsky, V. G. Zhytomyrsky, Y. A. Kuznetsov, M. P. Spedarets, G. V. Rubina, Y. A. Pervin, etc.). The question of studying the psychological and pedagogical bases of IT use in the educational process is devoted to no less than a number of studies (R. Williams, K. Klayman, S. Peypert, V. V. Davydov, V. V. Rubtsov, T. V. Minkovich, I. V. Levchenko, G. L. Lukain, I. V. Robert, etc.). At the same time, the analysis of modern researches showed that the problems of IT implementation in the process of studying at universities are not paid proper attention, as a result of which there are problems of a psychological and pedagogical nature when studying on the basis of IT, the research of which is currently engaged in A. A. Andreev, V. I. Soldatkin, A. V. Solovyov, S. A. Ilyushin, B. L. Sobkin and others. (Andreyev, 2005: 2) The need to use IT in universities can be considered through the prism of psychological characteristics of students in the economic direction of education, the development of their cognitive processes, without which human activity is impossible. Students of higher preschool universities are distinguished by sharpness and fresh perception, actively and with interest perceive the environment and everything new.

At this age, spontaneous attention is formed, which becomes especially concentrated and stable, in case of predominance of visuals in the lesson, which causes the brightness of the emotional attitude. A huge flow of new information, advertising, the use of computer technologies on television, the distribution of game consoles, electronic toys and computers greatly affect the upbringing of the child and his perception of the world around him. Therefore, the use of IT in educational and extracurrent activities in universities looks very natural, and is one of the effective ways to increase motivation and individualize his teachings, develop creative abilities and create a favorable emotional background.

Clarity, if we keep in mind by it all possible options for influencing the senses of the student, is also justified by Y. A. Kamensky, who called it the "golden rule of didactics" and demanded that everything that is possible be imagined for perception by feelings (Anufriyeva, 2009: 3). Modern information technologies have wide opportunities to implement this rule, which must be implemented on the basis of taking into account the psychological characteristics of perception of information by children of primary school age in the process of studying. In the educational interaction between the teacher and the child, one of the most relevant problems is to attract and maintain attention throughout the lesson. K. D. Ishinsky considered attention one of the most important factors contributing to the success of learning. they are recommended to teachers several means of preserving attention: increased impression, direct demand of attention, measures against inattention, curiosity of teaching. These funds are inherent in IT, which have a wide range of expressive, artistic and technical capabilities, as they make it easy to enhance the impression of the material being taught (Voronina, 2005: 6). It plays an important role in memorize as a logical completion of the assimilation process. They contribute to the strengthening of the knowledge gained, creating bright support points, help to reflect the logical thread of the material, to systematize the material studied. Especially should be taken into account by the teacher the emotional impact of information. If it is necessary to concentrate the attention of students in the economic direction of learning on the content of the proposed material, then the strength of emotional impact by IT causes interest and positive emotional mood among students in the economic direction of learning for the entire perception process.

Currently, the main task of education is not only to obtain certain knowledge by children, but also to form the skills and abilities of independently obtaining this knowledge. Practice shows that students in the economic direction of education, who are actively working with the computer, form a higher level of skills, the ability to navigate in a powerful flow of information. They know how to highlight the main thing, summarize, draw conclusions. At the same 
time, the role of a university teacher in unlocking the possibilities of new computer technologies in the learning process is very important. The combination of IT is associated with two types of technologies: information and communication. Information technology is a complex of methods, methods and means that provide storage, processing, transmission and display of information and focused on improving efficiency and productivity. At the present stage, methods, methods and means are directly interconnected with the computer (computer technologies).

It plays an important role in memorize as a logical completion of the assimilation process. They contribute to the strengthening of the knowledge gained, creating bright support points, help to reflect the logical thread of the material, to systematize the material studied. Especially should be taken into account by the teacher the emotional impact of information.

If it is necessary to concentrate the attention of students in the economic direction of learning on the content of the proposed material, then the strength of emotional impact by IT causes interest and positive emotional mood among students in the economic direction of learning for the entire perception process. Currently, the main task of education is not only to obtain certain knowledge by children, but also to form the skills and abilities of independently obtaining this knowledge. Practice shows that students in the economic direction of education, who are actively working with the computer, form a higher level of skills, the ability to navigate in a powerful flow of information. They know how to highlight the main thing, summarize, draw conclusions. At the same time, the role of a university teacher in unlocking the possibilities of new computer technologies in the learning process is very important.

The combination of IT is associated with two types of technologies: information and communication. Information technology is a complex of methods, methods and means that provide storage, processing, transmission and display of information and focused on improving efficiency and productivity. At the present stage, methods, methods and means are directly interconnected with the computer (computer technologies).

Information technologies of training - a set of methods and technical means of collecting, organizing, storing, processing, transmitting, and presenting information that expands people's knowledge and their developing capabilities for managing technical and social processes. E. I. Mashbitz and N. F. Thalizina consider information technology of learning as a certain set of educational programs of various types: from the simplest programs that provide knowledge control, to educational systems based on artificial intelligence (Voronina, 2005: 6).

The main direction of the process of informatization of modern society is the informatization of education, which is a system of methods, processes and software and hardware integrated for the purpose of collecting, processing, storing, disseminating and using information using a computer. it becomes clear that informatization imposes its imprint directly on the activities of people, educators and students of the economic direction of education. Before them open wider prospects in obtaining, storing, processing, transmitting, processing a wide variety of information.

The purpose of informatization: to develop the intellectual activity of students in the economic direction of study through the use of new IT, which make it possible to competently form cognitive activity during the educational process; make learning more effective by attracting all kinds of perceptions of students in the economic direction of study; to build such an education system that will contribute to the high absorption of the material under study; to involve in the process of active learning different categories of students in the economic direction of study; use specific computer properties that allow you to individualize the educational process and turn to fundamentally new cognitive tools (Voronina, 2005: 6).

It is obvious that modern education is a continuous process. Therefore, it is already necessary to organize the learning process on the basis of modern IT, where information communication means are increasingly used as sources of information. The introduction of new information and communication technologies based on the Internet today is one of the most important reserves for improving the effectiveness of continuous education and self-education of pedagogical workers. According to V. V. Mytin today there is only a conditional boundary between information and information-communication technologies. Experts know the close relationship of these technologies and believe that when talking about information technologies, they almost always mean information and communication technologies.

The use of IT in modern universities is not only expedient, but also relevant and will allow achieving one of the goals set by teachers "Concept of modernization of education" - the preparation of a versatile developed personality. Today it is difficult to imagine an educational organization in which there would be no IT.

Thus, the use of IT allows you to solve a number of problems in training. First, it is difficult for students 
in the economic direction of education to set goals that stimulate the active participation of the child in the educational process. Prestigious work, successful career, mastering the centuries-old experience of mankind for students in the economic direction of study are relevant. In this regard, to increase motivation uses close goals to learn the alphabet and learn the score, not to upset mom, to read faster than his comrade. The difficulty is that university students are becoming more infantile, so these goals may not become stimulating for the child.

Modern computer learning systems put in front of children of older preschool age a real, understandable, quite achievable goal: you will decide right - open the picture, insert all the letters correctly - move closer to the goal of a fairy-tale hero. Thus, in the process of playing, the child has a positive motivation for learning knowledge. Learning is the foundation on which all further human activities will be built.
The teacher faces a responsible task - to achieve the assimilation of program material in full by each child.

The development of IT opens up fundamentally new didactic and psychological opportunities for the fields of preschoolers' education. The computer naturally fits into the life of the kindergarten, is another effective technical tool with the help of which you can significantly diversify the learning process.

The use of computers in education has already ceased to be an unusual phenomenon. Characteristics and capabilities of modern personal computers and software are constantly improving. The ability of the computer to reproduce information simultaneously in the form of text, graphic image, sound, language, video, memorize and with great speed to process data allows specialists to create new means of study for students in the economic direction of learning, which are fundamentally different from all existing traditional materials.

\section{BIBLIOGRAPHY}

1. Андреев А. А. Средства новых информационных технологий (информационных технологий) в образовании: систематизация и тенденции развития. Москва, 1995.

2. Андреев А. А. Педагогическая модель компьютерной сети. Педагогическая информатика. 2005. № 2.

3. Ануфриева 3. Д. Мотивационный менеджмент педагогических кадров. Управление дошкольным образовательным учреждением. 2009. № 8.

4. Башмаков М. И., Поздняков С., Резник Н. А. Информационная среда обучения. Санкт-Петербург, СВЕТ, 1997.

5. Волокитин К. П. Современные информационные технологии в управлении качеством образования. Информатика и образование. 2000. № 8.

6. Воронина Т. П. Философские проблемы образования в информационном обществе. Москва : Весна, 2005.

7. Дорохин А. В., Дорохин О. В. Интернет как инновационная технология социального управления. Первая международная конференция «Социология инноваџий: теория и практика». Москва, 2006.

\section{REFERENCES}

1. Andreyev A. A. Sredstva novykh informatsionnykh tekhnologiy (informatsionnykh tekhnologiy) v obrazovanii: sistematizatsiya i tendentsii razvitiya [Means of new IT (information technologies) in education: systematization and development trends]. Moskva, 1995 [in Russian].

2. Andreyev A. A. Pedagogicheskaya model' komp'yuternoy seti [Pedagogical model of computer network]. Pedagogicheskaya informatika. 2005, № 2 [in Russian].

3. Anufriyeva Z. D. Motivatsionnyy menedzhment pedagogicheskikh kadrov [Motivational management of pedagogical staff]. Upravleniye doshkol'nym obrazovatel'nym uchrezhdeniyem. 2009. № 8 [in Russian].

4. Bashmakov M. I., Pozdnyakov S., Reznik N. A. Informatsionnaya sreda obucheniya [Information environment of training]. Sankt-Peterburg, SVET, 1997 [in Russian].

5. Volokitin K. P. Sovremennyye informatsionnyye tekhnologii V upravlenii kachestvom obrazovaniya [Modern information technologies in education quality management]. Informatika i obrazovaniye, 2000. № 8 [in Russian].

6. Voronina T. P. Filosofskiye problemy obrazovaniya $\mathrm{v}$ informatsionnom obshchestve [Philosophical problems of education in the information society]. Moskva, Vesna, 2005 [in Russian].

7. Dorokhin A. V., Dorokhin O. V. Internet kak innovatsionnaya tekhnologiya sotsial'nogo upravleniya [Internet as an innovative technology of social management]. Pervaya mezhdunarodnaya konferentsiya "Sotsiologiya innovatsiy: teoriya i praktika”. Moskva, 2006 [in Russian]. 